\begin{tabular}{|l|c|c|c|c|}
\hline $\begin{array}{l}\text { Cuadernos de Investigación Geográfica } \\
\text { Geographical Research Letters }\end{array}$ & 2020 & N $^{\circ} 46(1)$ & pp. 141-158 & eISSN 1697-9540 \\
\hline
\end{tabular}

\title{
SPATIAL DISTRIBUTION OF ACTIVE AND INACTIVE ROCK GLACIERS AND PROTALUS RAMPARTS IN A SECTOR OF THE CENTRAL ANDES OF ARGENTINA
}

\author{
C.D. VILLARROEL*, A.P. FORTE \\ Centro de Investigación de la Geósfera y Biósfera - Consejo Nacional de Investigaciones Científicas y \\ Técnicas (CIGEOBIO - CONICET), Argentina
}

\begin{abstract}
Rock glaciers and protalus ramparts are two of the main morphological features of the Central Andes in the Province of San Juan, Argentina. This sector of the Andes has one of the highest densities of occurrence of rock glaciers in the world. In this region, which has semiarid climatic characteristics, the presence of these landforms is important due to their solid state water reserves and as water resource regulators. Their occurrence is vital in several basins where, due to the lack of glaciers, debris-covered glaciers and perennial snow patches, rock glaciers are the only solid-state water reserves. However, the topo-climatic factors controlling the development and evolution of rock glaciers and protalus ramparts are not well known, which prevents an integrated management of the basins. This contribution, first, analyzes the spatial distribution of active and inactive rock glaciers and of protalus ramparts with respect to different topographic variables in the upper section of the Santa Cruz River basin. In total, 375 landforms have been inventoried, out of which 83 are active rock glaciers, 81 are inactive and 211 are protalus ramparts, covering an area of $13.09 \mathrm{~km}^{2}$ (3.03\% of the total area). The active periglacial environment belt occurs between 4000 and $4200 \mathrm{~m}$ a.s.l. and slopes with a southwesterly aspect have a greater development of active rock glaciers. Secondly, the evolution of such landforms is addressed. While the development of protalus ramparts does not seem to be mainly controlled by the topographic variables analyzed, the evolution of protalus ramparts in rock glaciers would be mainly controlled by elevation and aspect. Besides, there are local topoclimatic factors that contribute to the development of such landforms.
\end{abstract}

Distribución espacial de glaciares de escombros activos e inactivos y protalus ramparts en un sector de los Andes Centrales de Argentina

RESUMEN. Los glaciares de escombros y protalus ramparts son dos de los principales rasgos morfológicos de los Andes Centrales en la provincia de San Juan, Argentina. Este sector de los Andes tiene una de las mayores densidades de presencia de glaciares de escombros en el mundo. En esta región, con 
características climáticas semiáridas, la presencia de estas geoformas es importante por sus reservas hídricas en estado sólido y como reguladores de estos recursos. Esta importancia es vital en varias cuencas donde, debido a la inexistencia de glaciares, glaciares cubiertos y manchones de nieve perennes, son la única reserva hídrica en estado sólido. Sin embargo, son poco conocidos los factores topo-climáticos que controlan el desarrollo y evolución de estos glaciares de escombros y protalus ramparts, lo cual impide una gestión integral de las cuencas. En esta contribución se estudia, en primer lugar, la distribución espacial de glaciares de escombros activos, inactivos y protalus ramparts en relación con diferentes variables topográficas en el tramo superior de la cuenca del río Santa Cruz. En total han sido inventariadas 375 geoformas, de las cuales, 83 son glaciares de escombros activos, 81 inactivos y 211 protalus ramparts, ocupando un área de 13,09 $\mathrm{Km}^{2}$ (3,03\% de la superficie total). La banda altitudinal entre 4000 y 4200 m s.n.m. de ambiente periglacial activo y las laderas con orientación suroeste son las de mayor desarrollo de glaciares de escombros activos. En segundo lugar, se analizó la evolución de estas geoformas. En el desarrollo de protalus ramparts ninguna de las variables topográficas analizada parecería tener una influencia destacada. Pero la evolución de protalus ramparts hacia glaciar de escombros sí estaría controlada principalmente por la altitud y orientación. Existen además factores topo-climáticos locales que contribuyen al desarrollo de dichas geoformas.

Key words: Periglacial environment, rock glacier, protalus rampart, Central Andes.

Palabras clave: Ambiente periglacial, glaciar de escombros, protalus rampart, Andes Centrales.

Received: 21 May 2019

Accepted: 4 June 2019

*Corresponding author: Cristian Daniel Villarroel, Centro de Investigación de la Geósfera y Biósfera - Consejo Nacional de Investigaciones Científicas y Técnicas (CIGEOBIO CONICET), Argentina. E-mail address: cristian.villarroel@unsj-cuim.edu.ar

\section{Introduction}

The cities and economic activities that occur at the foot of the Argentine Central Andes (Lliboutry, 1998) are supported by and depend almost exclusively on permanent watercourses and groundwater that originate in the headwaters of the Andean basins. In general, this region is characterized by semiarid climatic conditions, with limited water resources that depend on the contributions of snow, glacier and permafrost melting (Masiokas et al., 2016). The occurrence of periglacial environment landforms, mainly rock glaciers, becomes even more important in areas in which there are no glaciers, perennial snow patches or debris-covered glaciers, as they are the only solid-state water 
reserves. However, the characteristics and processes occurring in permafrost mountain environments (Haeberli et al., 2006) in these regions have not been studied in depth; therefore, a better understanding is absolutely necessary for the appropriate use and management of the water resources.

The Central Andes are characterized by the high density of rock glaciers and protalus ramparts (Barsch, 1996), among other typical landforms of the periglacial environment (Trombotto et al., 1999). Active rock glaciers are considered by Barsch (1992) to be the expression of mountain permafrost, with their minimum elevation being a good indicator of the minimum elevation of the surfaces with a higher probability of occurrence of permafrost (Azócar et al., 2016). Nevertheless, neither the involvement of these landforms in the water cycle nor their characteristics and processes are known well enough for the appropriate use of the territory. This study focuses on intact rock glaciers (Barsch, 1996) - a category including both active and inactive rock glaciers and protalus ramparts, whose spatial distribution and morphological, morphometric and topographic characteristics have allowed a preliminary characterization of the territory.

Previous studies in the central west region in Argentina regarding the spatial distribution of periglacial landforms can be found in Corte and Espizua (1981), Aguado (1983), Bottero (2002), Perucca and Esper Angillieri (2008), Esper Angillieri (2009), Perucca et al. (2011), Villarroel (2013), Trombotto et al. (2012), Tapia and Trombotto (2015), Forte and Villarroel (2015) and Forte et al. (2016). Similar studies on the distribution of permafrost have been undertaken previously in other locations (Brenning et al., 2007; Johnson et al., 2007; Azócar et al., 2016). In the Province of San Juan, other types of studies on the periglacial environment have been carried out by Schrott (1996), Croce and Milana (2002), Scholl (2002), Arenson et al. (2010), Tapia et al. (2016), Forte et al. (2013) and Villarroel et al. (2016, 2018).

The aim of this survey is to analyze the spatial distribution of active and inactive rock glaciers and protalus ramparts as regards different topographic variables, such as elevation, aspect and slope.

In Argentina, a national law for the protection and preservation of the glacial and periglacial environment has been passed, which has given an impetus to the research and generation of knowledge in the field. The results of this work entail a significant progress to find out the number, characteristics and spatial distribution of periglacial landforms in the Argentine Central Andes, with such information being of relevance to future research on their involvement in the hydrological systems.

\subsection{Study area}

This survey has been undertaken at the headwaters of a basin in the Argentine Central Andes, corresponding to the upper section of the Santa Cruz River basin, from its sources to the confluence with the Pachón River (Fig. 1), in the southwestern sector of the department of Calingasta, Province of San Juan. It extends between latitudes $31^{\circ} 44^{\prime}$ and $31^{\circ} 55^{\prime} \mathrm{S}$ and longitudes $70^{\circ} 11^{\prime}$ and $70^{\circ} 28^{\prime} \mathrm{W}$, and it is bounded to the west and 
southwest by the Republic of Chile, to the east by the Santa Cruz range and to the north by the watershed of the Carniceria River basin (Fig. 1).

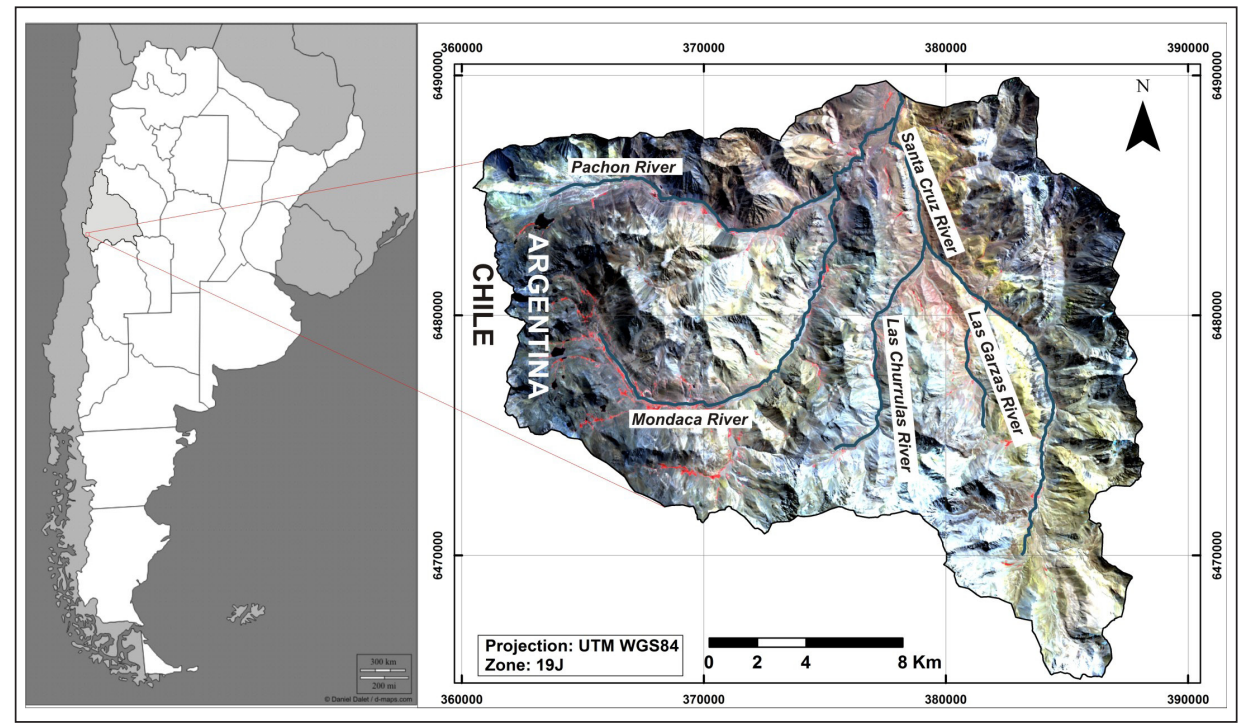

Figure 1. Location of the study area. The western and southwestern limits coincide with the international border between the Argentine Republic and the Republic of Chile.

\section{Regional framework}

\subsection{Geological framework}

The Cordillera Principal geological province (Yrigoyen, 1972) is divided into three sectors. The southern sector corresponds to La Valenciana or Malargüe fold and thrust belt (Kozlowski et al., 1993; Manceda and Figueroa, 1995). The central sector comprises the Aconcagua fold and thrust belt (Yrigoyen, 1976; Ramos, 1985a), whereas the northern sector, where the study area is located, is characterized by the thick-skinned east-vergent La Ramada fold and thrust belt (Ramos et al., 1996a). Even though the surface structure in the region of La Ramada shows evidence of a Cenozoic compressive deformation as a result of the Andean orogeny, relict features of a Triassic extensional deformationwhose inversion occurred during the upper Cenozoic - can be observed in it (Alvarez and Ramos, 1999; Cristallini and Ramos, 2000). The stratigraphic sequence present in this sector is associated with the Mesozoic sediment infill of the La Ramada basin and the overlying Cenozoic volcanic rocks. This sequence has three main elements: a preJurassic basement, a Mesozoic cover - composed of the Triassic-Jurassic basin infill and Cretaceous continental deposits with associated volcanic rocks - and a Tertiary volcanic cover, discordantly overlain by Quaternary deposits. 


\subsection{Climatic-geomorphological framework}

Geomorphological processes are influenced directly by climatic particularities. The study area is located immediately to the south of the major physiographic region known as the South American Arid Diagonal, characterized by its pronounced aridity, which traverses the South American subcontinent from the northwest to the southeast, occupying a large percentage of its surface area. In addition, the Argentine Central Andes constitute one of the highest locations in the continent, with mountains that reach heights of over $6000 \mathrm{~m}$ and inter-montane valleys with significant widths and development. Such a steep topography causes greatly variable and discontinuous climatic characteristics in the area. Precipitations, mainly snow, occur mostly during the winter, ranging between 300 and $400 \mathrm{~mm} / \mathrm{m} 2$ a year in the study area (Arenson et al., 2010). Their characteristics are variable and are closely linked to the state of El Niño phenomenon (El Niño-Southern Oscillation or ENSO) (Masiokas et al., 2006; Corripio et al., 2007). During the warm ENSO phases, air temperatures are higher, which fosters the occurrence of snowstorms and increases the cloud cover and the albedo in the area (Leiva et al., 2007). Most of the precipitation originates in the Pacific Ocean. This portion of the Central Andes is leeward of the large wet air masses from the Pacific. Besides, this context leads to the predominance in the area of a Föhn wind effect, whose dry and warm air masses descend from the high peaks to the populated valleys of central-west Argentina, locally known as Zonda wind, with a northwesterly-southeasterly main wind direction. That is the reason why the Chilean side of the Central Andes receives more precipitation than the Argentine one (Strecker et al., 2007). However, the Argentine portion also receives sporadic precipitation contributions from the east, originating in the Atlantic Ocean (Bolius et al., 2006; Jenk et al., 2015). Available data of the region have made it possible to construct a mean annual air temperature (MAAT) model, which establishes a value of $-2.15^{\circ} \mathrm{C}$ at $4019 \mathrm{~m}$ a.s.1. For the summer months, this model estimates a MAAT value of $3.88{ }^{\circ} \mathrm{C}$, whereas for the winter months, a value of $-7.47^{\circ} \mathrm{C}$. The minimum absolute temperature measured in winter is $-23.9^{\circ} \mathrm{C}$, and the maximum absolute temperature in summer is $17^{\circ} \mathrm{C}$ (Tapia and Trombotto, 2016).

As regards the geomorphology, a relief shaped by the major Pleistocene glaciations prevails. There is ample development of glacial erosion landforms, such as striations, U-shaped valleys, asymmetric valleys, roche moutonnées, ancient cirques and arêtes, and truncated spurs, among others. Glacial accumulation landforms are also typical in the area, in particular basal, lateral, frontal and terminal moraines, erratic blocks and other till deposits. The glacial environment has receded from such maximum extension, until its complete extinction in the area. At present, all of the glacial deposits are being reworked by periglacial, gravitational and fluvial processes. Among the periglacial landforms, solifluction/gelifluction slopes and a large number of active and inactive rock glaciers stand out, as well as other minor landforms, such as protalus ramparts, patterned grounds and stone rings. Regarding the gravitational processes, there are a large number of landslides, in certain cases associated with periglacial processes, as is the case of active layer failures. Lacustrine deposits and present-day lakes are usually associated with moraines and mass removal deposits. 


\section{Methodology}

In order to recognize, describe, classify and map the different landforms, images obtained by the CBERS-2B, SPOT and Terra satellites were used (Table 1). The SPOT satellite images were provided by the Comisión Nacional de Actividades Espaciales (CONAE; National Space Activities Commission) through the agreement between the National University of San Juan and the CONAE. The Terra and CBERS-2B images were downloaded for free from the website of the US Geological Survey (https://earthexplorer. usgs.gov/) and the Brazilian Instituto Nacional de Pesquisas Espaciais (INPE, National Institute for Space Research) (http://www.inpe.br/), respectively. In addition, satellite images of excellent spatial resolution of Google Earth (Digital Globe) have also been used. The mapping of periglacial landforms has been undertaken manually in a GIS (Geographic Information System) environment.

Table 1. identification and characteristics of satellite images used in this work.

\begin{tabular}{|l|l|l|l|c|}
\hline Satellite & Sensor & ID Image & Date & Resolution \\
\hline Landsat 8 & OLI & LC82330822016063LBN00 & $03 / 03 / 2016$ & 15 meters \\
\hline Terra & Aster & AST14OTH_00304012012145020 & $01 / 04 / 2012$ & 15 meters \\
\hline Cbers 2B & HRC & 176_A_136_1 & $08 / 04 / 2009$ & 2.7 meters \\
\hline Cbers 2B & HRC & 176_C_136_2 & $26 / 06 / 2008$ & 2.7 meters \\
\hline Cbers 2B & HRC & 176_C_136_3 & $01 / 12 / 2007$ & 2.7 meters \\
\hline SPOT 6 & NAOMI & Spot6_20160121_1428359_bundle_w070s31_12a_16jr_060x256_32719 & $21 / 01 / 2016$ & 1.5 meters \\
\hline SPOT 7 & NAOMI & Spot6_20151213_1425525_bundle_w070s32_12a_16jr_058x061_32719 & $13 / 12 / 2015$ & 1.5 meters \\
\hline
\end{tabular}

The Digital Elevation Model (DEM) used was the ASTER GDEM2, with a spatial resolution of $30 \mathrm{~m}$ x $30 \mathrm{~m}$. It was used to calculate the different physical parameters (maximum, mean and minimum elevations, aspect and average slope) of the landforms. All of the calculations were carried out using Quantum GIS free software (Quantum GIS Development Team, 2016. Open Source Geospatial Foundation Project) (http:// qgis.osgeo.org).

For the classification of the different landforms, morphological criteria were used (Wahrhaftig and Cox, 1959; Barsch, 1992; Ikeda and Matsuoka, 2006). Even though in order to establish the degree of activity of a rock glacier, the measurement of the surface flow is required, an accurate morphological description makes it possible to infer their degree of activity with acceptable precision (Martini et al., 2013). The morphological criteria that were taken into consideration to classify the different rock glaciers depending on their activity are the talus slope, the occurrence of fine debris and a talus arrangement, the presence of blocks at the talus feet, slide marks in the talus, presence of vegetation, occurrence and development of ridges and furrows, thermokarst and evidence of weathering in the exposed faces of the blocks (Fig. 2). The demarcation of each of the 

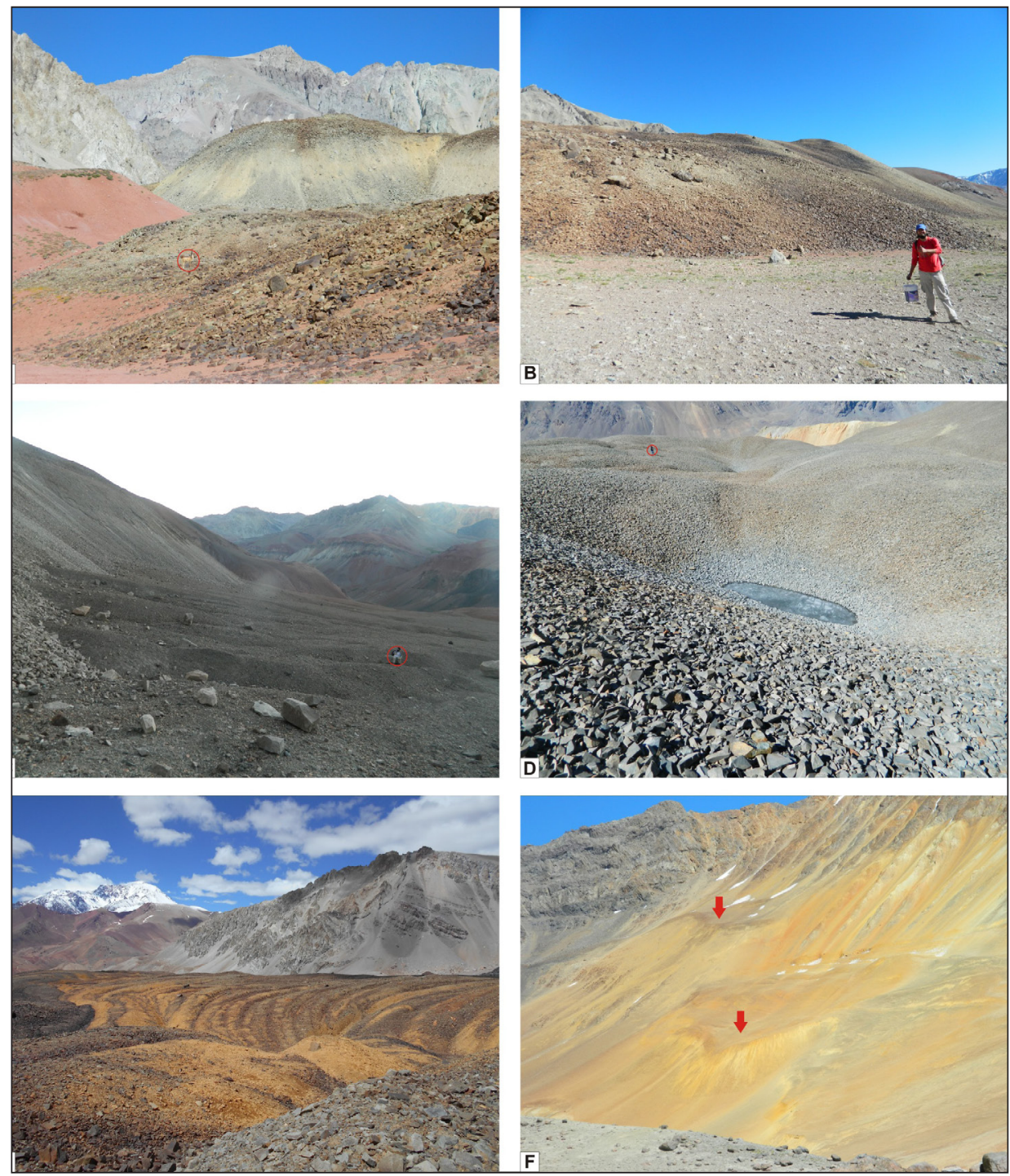

Figure 2. Morphological criteria used in the classification of rock glaciers according to their activity. (A) Frontal talus of an active rock glacier with a slope greater than $35^{\circ}$. In red circle, an animal for scale. (B) Frontal talus of an inactive rock glacier with a slope $<$ than $30^{\circ}$. The frontal slope of active rock glacier is steeper due to the greater abundance of ice that acts as a support for the detritus. (C) Frontal talus of an active rock glacier. At the talus feet, presence of fallen blocks. In red circle, seated person for scale. (D) Surface morphology of a rock glacier showing the presence of a thermokarst with frozen water at the bottom. In red circle a person for scale. The thermokarst can be indicators of areas with local permafrost degradation. (E) Typical structure of curved furrows and ridges well developed on the surface of the rock glacier. This structure and its degree of conservation are indicative of movement. $(F)$ Two protalus ramparts hanging on a hillside. These landforms are the incipient manifestation of creeping permafrost. 
rock glaciers was set at the base of the lateral and frontal taluses, whereas in the root area, the limit was set where a pronounced change in slope occurs. Field ground control was carried out on the basis of certain morphological parameters, such as the measurement of the talus slope, the presence of fine debris, and evidence of weathering. Such control was undertaken on $18 \%$ of the landforms inventoried. Geophysical studies (seismic refraction tomography and vertical electric sounding) carried out in two rock glaciers made it possible to confirm the degree of activity on the basis of the morphological characterization (Villarroel et al., 2016).

\section{Results and discussion}

\subsection{Amount and areal distribution}

Three hundred and seventy-five active and inactive rock glaciers and protalus ramparts have been inventoried; they cover an area of $13.09 \mathrm{~km}^{2}$, representing $3.03 \%$ of the total area of the basin $\left(432 \mathrm{~km}^{2}\right)$. Of the landform total, 83 bodies were regarded as active rock glaciers, 81 as inactive rock glaciers and 211 as protalus ramparts (Fig. 3).

\begin{tabular}{|c|c|c|c|}
\hline Landforms Type & Amount & \multirow{10}{*}{ Amount of Landforms } & \multirow{2}{*}{ Area of Lanforms } \\
\hline Active Rock Ghacier & 83 & & \\
\hline Inactive Rock Glacier & 81 & & \\
\hline Protalus Rampart & 211 & & \\
\hline Total & 375 & & Glacier \\
\hline "Landforms Type & Area $(\mathrm{Km} 2)$ & & - Inactive Rock \\
\hline Active Rock Glacier & 8.31 & & Glacier \\
\hline Inactive Rock Glacier & 3.3 & & $=$ Protalus \\
\hline Protalus Rampart & 1.48 & & \\
\hline Total & 13.09 & & \\
\hline
\end{tabular}

Figure 3. Amount and area covered according to type of landform.

Active and inactive rock glaciers represent the same percentage (22\%), with 83 and 81 bodies inventoried, respectively. In turn, protalus ramparts represent $56 \%$, with a total of 211 bodies inventoried, suggesting the greater predominance of protalus ramparts with respect to the total number of bodies. This situation is reversed when considering the area covered by each of these landforms, as active rock glaciers represent $64 \%-$ covering a total area of $8.31 \mathrm{~km}^{2}-$, followed by inactive rock glaciers - which cover $25 \%$ and an area of $3.3 \mathrm{~km}^{2}$, while, protalus ramparts only represent $11 \%$ of the area with a surface of $1.48 \mathrm{~km}^{2}$ (Fig. 3). This situation shows that, despite the large number of protalus ramparts, the area covered by them is very limited when compared with rock glaciers. On the other hand, active and inactive rock glaciers have practically the same number of bodies, but active rock glaciers cover an area 2.5 times larger than the one covered by inactive rock glaciers.

Depending on the size of area (Fig. 4), it can be observed that in the smallest-sized category, the presence of protalus ramparts and inactive rock glaciers predominates. Eighty- 
five percent of the inactive rock glaciers and $99.5 \%$ of the protalus ramparts inventoried correspond to this category, whereas active rock glaciers only represent $46 \%$. In the rest of the size categories, active rock glaciers predominate. On average, the size of active rock glaciers is 10.01 ha, with a maximum size of 85.74 ha and a minimum size of 0.65 ha. In turn, inactive rock glaciers have an average size of 4.08 ha, with a maximum size of 40.8 ha and a minimum size of $0.28 \mathrm{ha}$. In the case of protalus ramparts, as they are embryogenic landforms, their average size is much smaller than the above-mentioned ones.

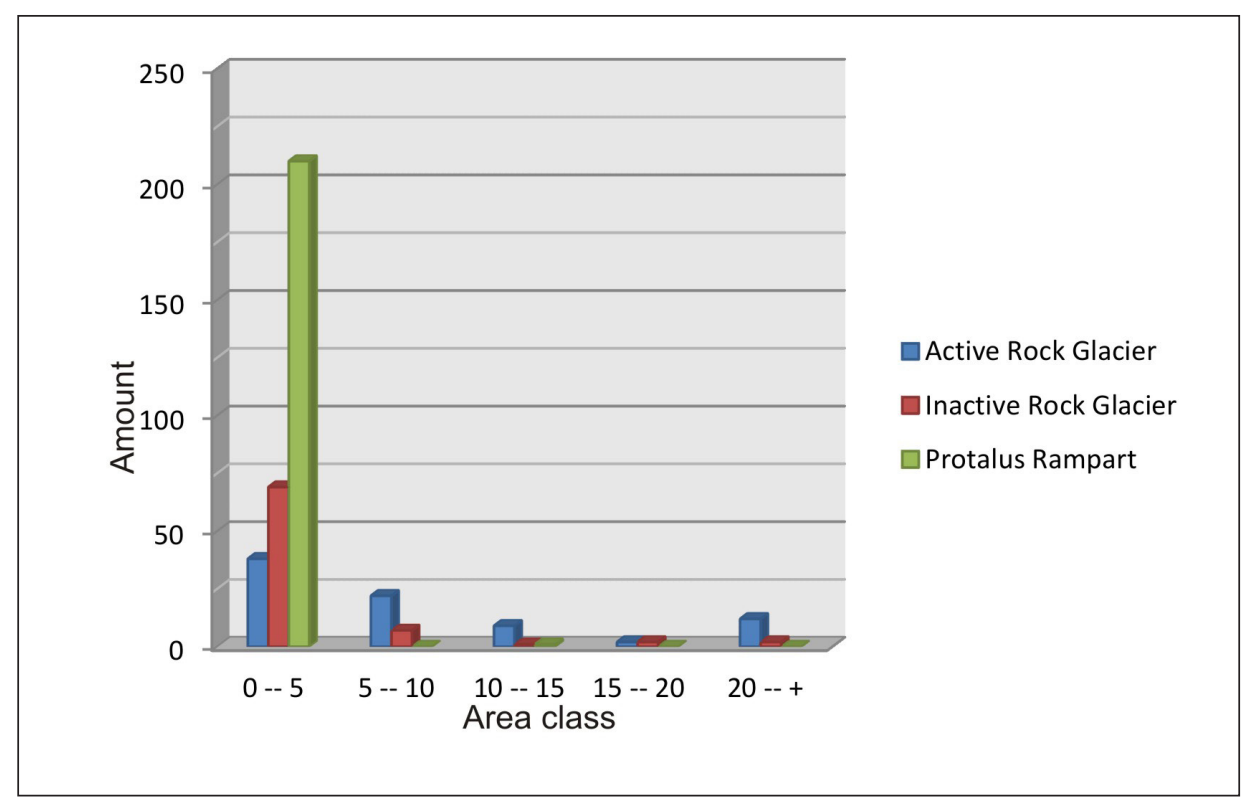

Figure 4. Distribution of landforms by type of area.

\subsection{Altitudinal distribution}

The elevations in the study area range between 3025 and $5018 \mathrm{~m}$ a.s.l. At a local level, the minimum elevations at which active and inactive rock glaciers occurs are 3593 and $3457 \mathrm{~m}$ a.s.l., respectively. On the other hand, the maximum elevations in the case of active and inactive rock glaciers are 4695 and $4544 \mathrm{~m}$ a.s.l., respectively.

The altitudinal distribution of intact rock glaciers and protalus ramparts shows that the optimal altitudinal belt range for the development of these periglacial landforms is between 3400 and $4700 \mathrm{~m}$ a.s.l., with such landforms representing $4.07 \%$ of the area.

This altitudinal belt was subdivided into three strips according to the areal predominance of active and inactive rock glaciers (Figs. 5 and 6), and they are referred to as:

Degrading periglacial environment (3400-3600 m a.s.1.): This strip is characterized by the areal predominance of inactive rock glaciers ( $81 \%$ of the intact rock glacier area). 


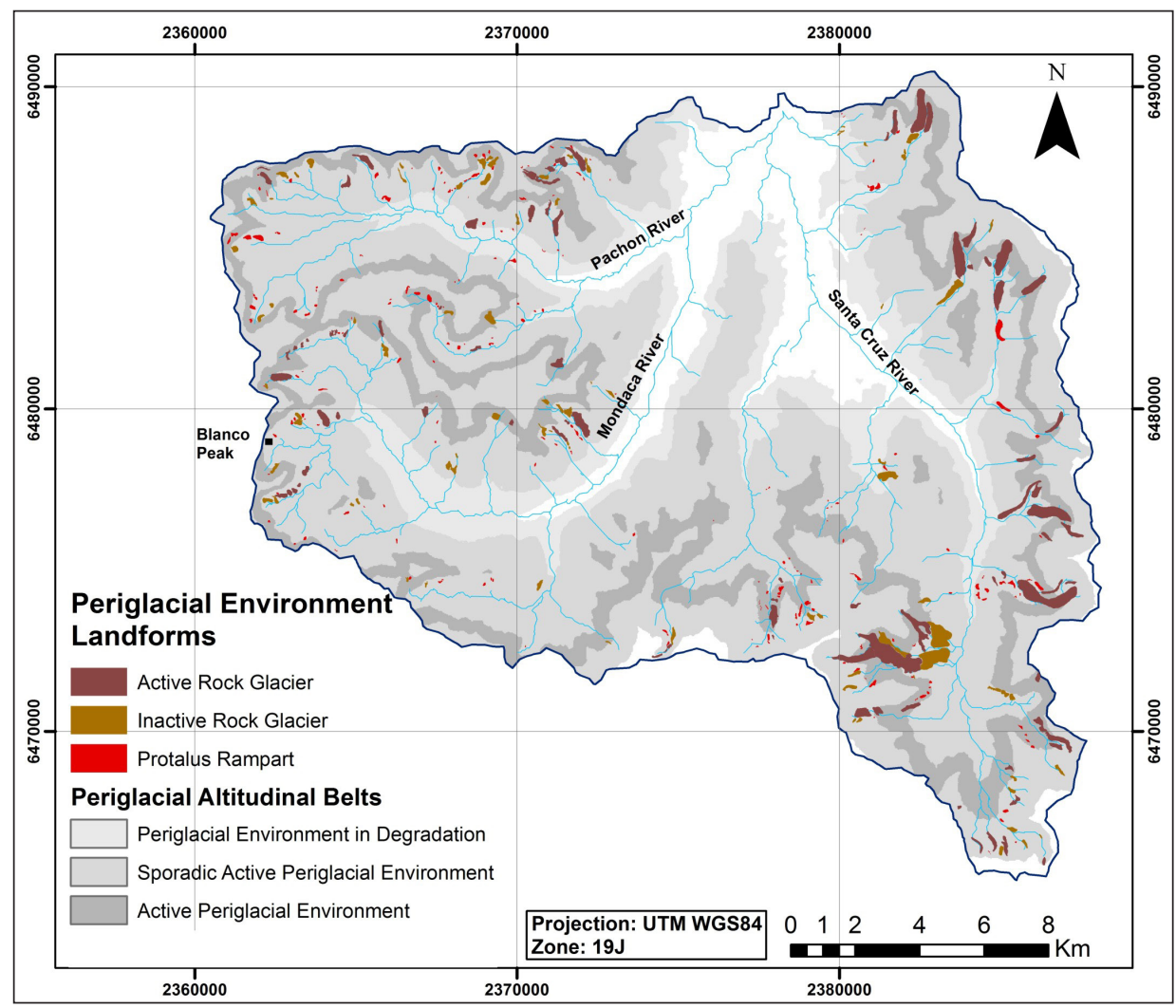

Figure 5. Inventory of active and inactive rock glaciers, and protalus ramparts. Subdivision into strips of the optimal altitudinal belt for the development of periglacial environment landforms.

- Sporadically active periglacial environment (3600-4000 m a.s.1./4200-4700 m a.s.l.): It is distinguished by a balanced distribution between active and inactive rock glaciers (58\% and $42 \%$ of the area, respectively). The lower part of this strip (3600-4000 $\mathrm{m}$ a.s.1.) shows greater development of both landforms in comparison with its upper part (4200-4700 m a.s.1.).

- Active periglacial environment (4000-4200 $\mathrm{m}$ a.s.1.): It is characterized by the predominance of active rock glaciers ( $90 \%$ of the area of intact rock glaciers).

In turn, protalus ramparts show an altitudinal range with a practically homogeneous development as regards the size of the area covered, between 3600 and $4100 \mathrm{~m}$ a.s.l. From that elevation up, their presence gradually decreases until they disappear at $4600 \mathrm{~m}$ a.s.1.

Regionally, the minimum elevation of occurrence of discontinuous permafrost as indicated by the terminus of active rock glaciers can be found at approximately 3700 m a.s.l. (Trombotto et al., 1997). In the Salinas River basin, in the north of the study 


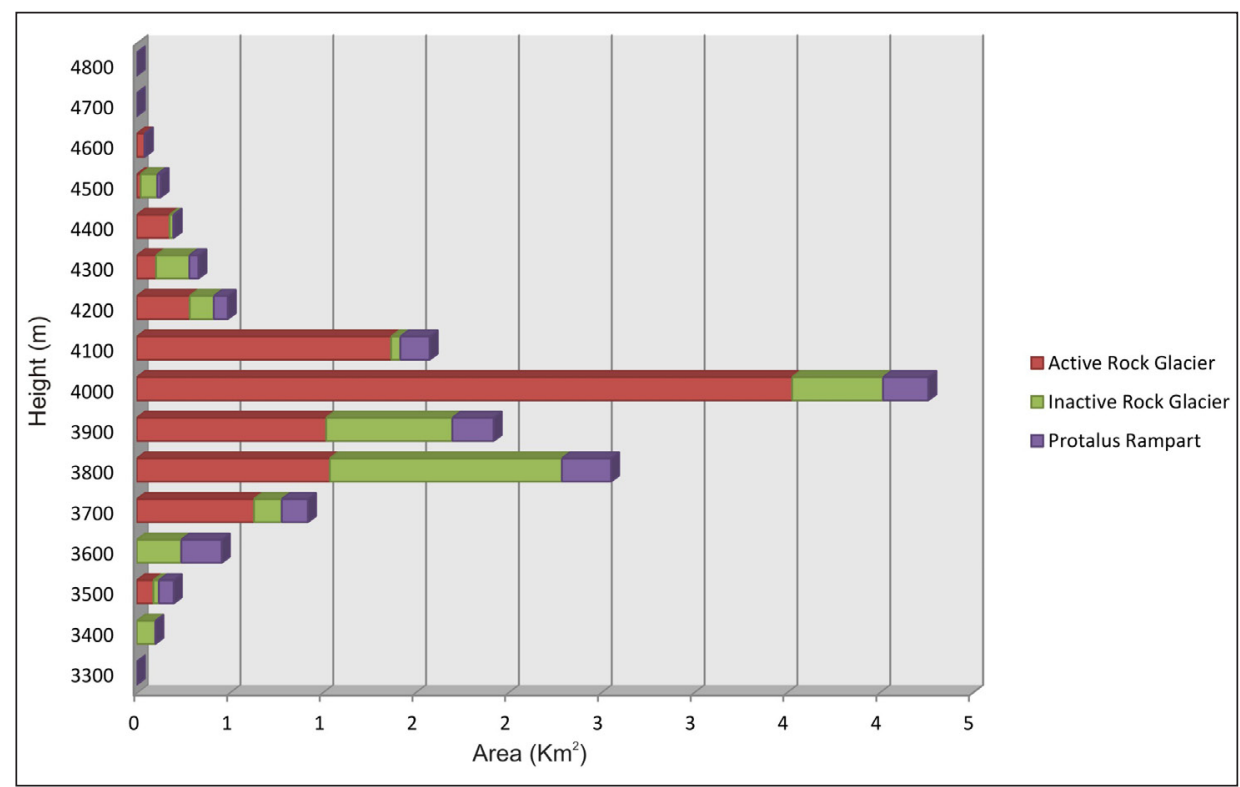

Figure 6. Altitudinal-areal distribution according to landform type.

area, such an elevation is of $3690 \mathrm{~m}$ a.s.1. (Forte et al., 2016b), whereas in La Ramada belt, in the south of the study area, it is $3670 \mathrm{~m}$ a.s.l. (Forte et al., 2016a).

According to Haeberli (1985), the terminus of active rock glaciers would approximately indicate the MAAT isotherm between -1 and $-2{ }^{\circ} \mathrm{C}$. Considering a normal temperature gradient for a mountain region $\left(-0.7{ }^{\circ} \mathrm{C} / 100 \mathrm{~m}\right)$ and taking as reference the MAAT of $-2.15{ }^{\circ} \mathrm{C}$ at $4019 \mathrm{~m}$ a.s.l. in the Paso de La Guardia weather stationlocated near the watershed of the Santa Cruz River basin (Tapia and Trombotto, 2015) - , the $0{ }^{\circ} \mathrm{C}$ isotherm would occur at $3660 \mathrm{~m}$ a.s.l., coinciding with the lower part of the sporadically active periglacial environment strip, whereas the $-2{ }^{\circ} \mathrm{C}$ isotherm would occur at $4000 \mathrm{~m}$ a.s.1. This indicates the occurrence of the terminus of certain rock glaciers below the $0{ }^{\circ} \mathrm{C}$ isotherm, while the $-2{ }^{\circ} \mathrm{C}$ isotherm coincides with the base of the active periglacial environment strip, a sector in which active rock glaciers greatly predominate.

\subsection{Aspect}

The general aspect of the periglacial landforms inventoried is predominantly southeasterly, southerly and southwesterly (Fig. 7). Analyzing the behavior according to the type of landform, it can be observed that active rock glaciers have predominantly southwesterly, southeasterly and southerly aspects. In turn, inactive rock glaciers have a marked southeasterly aspect. Protalus ramparts show a uniform development in practically every aspect, except in the northwesterly-facing slopes, where the number of protalus ramparts is very limited. 


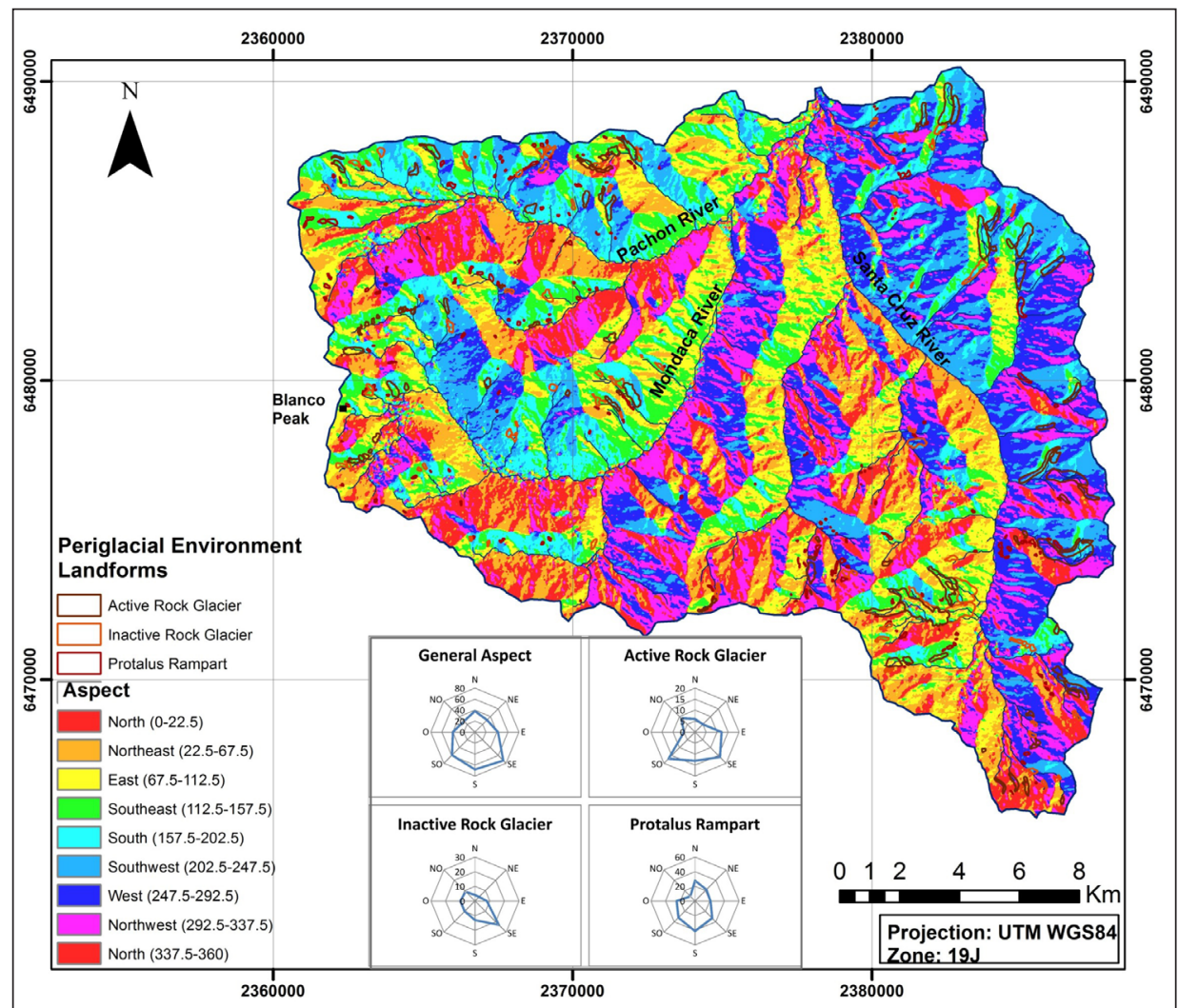

Figure 7. Aspect map and aspect according to the type of landform.

This general aspect of landforms towards south-facing slopes is consistent at a regional level with the fact that these receive less solar radiation (Schrott, 1991; Funk and Hoelzle, 1992). A particular situation can be observed in slopes with a northwesterly aspect. Protalus ramparts have a practically uniform distribution in every aspect, except in northwest-facing slopes, where there is a marked decrease in number. On the other hand, among the slopes with a northerly aspect $(\mathrm{N}, \mathrm{NE}$ and $\mathrm{NW})$, there is a peak of higher frequency of occurrence of active rock glaciers in the northwest-facing slopes. Considering protalus ramparts as embryogenic rock glaciers (Barsch, 1977; Haeberli, 1985; Scapozza et al., 2011), a greater development of rock glaciers could be expected where the number of protalus ramparts is greater; similarly, the development of rock glaciers from protalus ramparts would decrease their number. This situation can be clearly observed in slopes with a southerly aspect (S, SE and SW), where the frequency of occurrence of protalus ramparts is higher in southfacing slopes, followed by those with southeasterly and southwesterly aspects. In turn, the frequency of occurrence of active rock glaciers is the exact opposite, with a higher frequency in southwest-facing slopes, followed by those with southeasterly and southerly aspects. This would indicate the growth of rock glaciers from the development of protalus ramparts. Such 
a trend is repeated in northwest-facing slopes, where there is a high frequency of active rock glaciers and a very low frequency of protalus ramparts in comparison with the rest of the north-facing slopes. This would once again suggest that certain protalus ramparts have evolved into rock glaciers. However, slope aspect is a first approach towards the possibility of occurrence of periglacial environment landforms, due to the differences in intensity of the solar radiation received. Local topo-climatic factors would also play an important role in their development (Humlum, 1998). As it happens for example in La Ramada range where the steep topography has generated a shadow effect in the north-facing slopes, allowing the occurrence of a large number of landforms in them (Forte et al., 2016a).

\subsection{Slope}

$30.4 \%$ of the landforms inventoried have average slopes of between 30 and $40 \%$, whereas average slopes with values between 20 and $50 \%$ represent $75.75 \%$ of the landforms. In turn, average slopes greater than $60 \%$ only occur in $7.2 \%$ of the landforms and average slopes of less than $20 \%$ in $3.47 \%$ (Fig. 8).

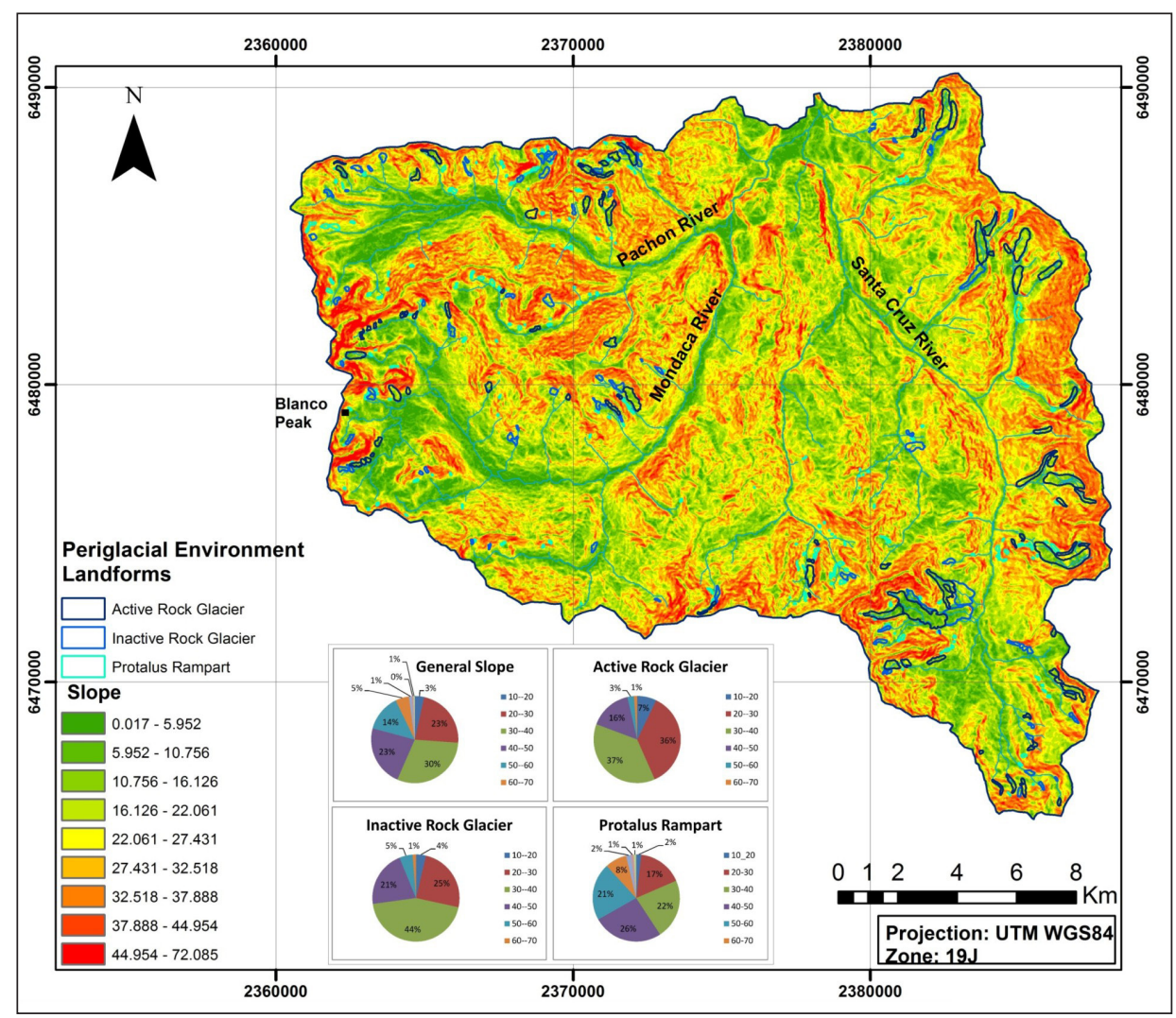

Figure 8. Slope map and average slopes according to the type of landform. 
As regards the average slopes, active and inactive rock glaciers have similar values. The average slope values ranging from 20 to $50 \%$ represent 89.15 and $90.12 \%$, respectively. In both types of landforms, there are no bodies with slopes of less than $10 \%$ or more than $70 \%$, with only one body with a slope of more than $60 \%$. In turn, protalus ramparts have average slope values that are slightly more scattered, with a concentration of $86.26 \%$ of the bodies with average slopes between 20 and $60 \%$. Unlike rock glaciers, there are protalus ramparts with average slope values greater than $70 \%$, with average slopes reaching $92 \%$ in certain bodies.

\section{Conclusions}

Elevation and aspect seem to be the two main topographic variables that may have exerted greater control on the spatial distribution of rock glaciers in this sector of the Central Andes.

Altitudinally, the optimal belt for the development of these periglacial landforms was subdivided into three strips according to the areal predominance of active and inactive rock glaciers. The degrading periglacial environment strip (3400-3600 m a.s.1.), which occurs below the $0{ }^{\circ} \mathrm{C}$ isotherm and where inactive rock glaciers predominate, would be indicating previous colder periods with the possible development of active rock glaciers at such heights. At present, the development of active rock glaciers in this strip would be the consequence of local topo-climatic conditions. There is a consistency between the altitudinal difference of the terminus of active and inactive rock glaciers, the altitudinal difference between the highest part of active and inactive rock glaciers, and the altitudinal difference between the lower limit of the degrading periglacial environment strip and the lower limit of the sporadically active periglacial environment strip, which in these cases is of approximately $150 \mathrm{~m}$.

At present, the optimal lower limit for the development of active rock glaciers is approximately at $3600 \mathrm{~m}$ a.s.1., although the optimal belt for the development of such landforms extends up to $4700 \mathrm{~m}$ a.s.1. There is a strip, in this work referred to as active periglacial environment (4000-4200 m a.s.1.), where their highest frequency occurs.

In the middle-latitude areas of the southern hemisphere, slopes with a general southerly aspect are the ones in which there is a higher frequency of occurrence of landforms, due to the fact that they receive less solar radiation. Active rock glaciers have a peak frequency of occurrence in the southwest-facing slopes, which would to a large extent be the result of the low solar radiation intensity received. In turn, northwestfacing slopes have a greater peak frequency of occurrence of landforms than the rest of the north-facing slopes, even though these receive higher solar radiation intensity, and therefore the possibility of developing such landforms decreases.

The development of protalus ramparts does not seem to be mainly controlled by any of the topographic variables analyzed. They develop in a broad altitudinal and slope range, and with every possible aspect. On the other hand, the evolution of protalus ramparts in rock glaciers may indeed be mainly influenced by elevation and aspect, although these 
may not be the only variables responsible for the spatial distribution of such landforms. Local topo-climatic factors should also be analyzed further for a deeper understanding.

The analysis of spatial distribution of periglacial landforms is of vital importance in semiarid areas, where their climatic, paleo-climatic, geomorphological and hydrological role is not well known yet. In turn, the methodology used in a SIG environment is inexpensive and simple to apply in other mountain regions.

\section{Acknowledgements}

The National Council of Scientific and Technical Research (CONICET) is acknowledged for having financed the studies that allowed the elaboration of this article. Dr. Eduardo Kruse is also thanked for his critical reading of the article that has allowed substantial improvements and for the translation of it. Finally, we thank the two anonymous reviewers who, with their suggestions and recommendations, have improved the quality of the manuscript.

\section{References}

Aguado, C.J. 1983. Comparación del inventario de glaciares de la cuenca del río de Los Patos con otros inventarios de los Andes Centrales de Argentina, con énfasis en glaciares de escombros. In: Actas de la primera reunión del grupo periglacial Argentino, Vol. 1, Mendoza, pp. 3-87.

Alvarez, P.P., Ramos, V.A. 1999. The Mercedario rift system in the Principal Cordillera of Argentina and Chile (32 SL). Journal of South American Earth Sciences 12, 17-31.

Arenson, LU., Pastore, S., Trombotto, D., Bölling, S., Quiroz, M.A., Ochoa, X.L. 2010. Characteristics of two Rock Glaciers in the arid Argentinean Andes based on initial surface investigations. In: Proceedings of the 63rd Canadian Geotechnical Conference / 6th Canadian Permafrost Conference.

Azócar, G.F., Brenning, A., Bodin, X. 2016. Permafrost Distribution Modeling in the Semi-Arid Chilean Andes, The Cryosphere Discussion. https://doi.org/10.5194/tc-2016-100.

Barsch, D. 1977. Eine Abschätzung von Schuttproduktion und Schuttransport in Bereich aktiver blockgletscher der Schweizer Alpen. Zeitschrift for Geomorphologie 28, 148-160.

Barsch, D. 1992. Permafrost creep and rock glaciers. Permafrost and Periglacial Processes 3 (3), 175-188.

Barsch, D. 1996. Rockglaciers. Indicators for the present and former geoecology in high mountain environments, Springer. Vol. 16, $331 \mathrm{pp}$.

Bolius, D., Schwikowski M., Jenk T., Gäggeler H. W., Casassa G., Rivera, A. 2006. A first shallow firn-core record from Glaciar La Ollada, Cerro Mercedario, central Argentine Andes. Annals of Glaciology 43, 14-22.

Bottero, R. 2002. Inventario de glaciares de Mendoza y San Juan. In: D. Trombotto, R. Villalba (Eds.), IANIGLA, 30 años de investigacion básica y aplicada en ciencias ambientales, Mendoza, pp 165-169.

Brenning, A., Grasser, M., Friend, D. 2007. Statistical estimation and generalized additive modeling of rock glacier distribution in the San Juan Mountains, Colorado, USA. Journal of Geophysical Research - Earth Surface 112, F02S15.

Corripio, J., Purves R., Rivera, A. 2007. Modeling climate-change impacts on mountain glaciers and water resources in the Central Dry Andes. Darkening Peaks: Glacier Retreat, Science and Society. University of California Press, pp. 126-135. 
Corte, A.E., Espizua, L.E. 1981. Inventario de glaciares de la cuenca del río Mendoza. IANIGLACONICET, Mendoza.

Cristallini, E.O., Ramos, V.A. 2000. Thick-skinned and thin-skinned thrusting in the La Ramada fold and thrust belt: crustal evolution of the High Andes of San Juan, Argentina (32 SL). Tectonophysics 317, 205-235.

Croce, F., Milana, J.P. 2002. Internal structure and behaviour of a rock glacier in the arid Andes of Argentina. Permafrost and Periglacial Processes 13, 289-299.

Esper Angillieri, M.Y. 2009. A preliminary inventory of rock glaciers at $30^{\circ} \mathrm{S}$ latitude, Cordillera Frontal of San Juan, Argentina. Quaternary International 195, 151-157.

Forte, A.P., Villarroel, C. 2015. Distribución altitudinal de diferentes tipos de glaciares de escombros y crioformas periglaciales. Cuenca del río Frío, San Juan, Argentina. In: Actas XIV Congreso Geológico Chileno, Coquimbo.

Forte, A.P., Güell, A.E., Villarroel, C.D. 2013. Tomografía sísmica en glaciares de escombros en las nacientes del arroyo Los Patos Norte. Calingasta, San Juan, Argentina. Bollettino di Geofisica Teorica ed Applicata 25, 263-265.

Forte, A.P., Villarroel, C.D. 2016a. Preliminary modeling of mountain permafrost on La Ramada Range. Central Andes, San Juan, Argentina. In: F. Günther, A. Morgenstern (Eds.), XI. International Conference On Permafrost - Book of Abstracts, Potsdam.

Forte, A.P., Villarroel, C.D., Esper Angillieri, M.Y. 2016b. Impact of natural parameters on rock glacier development and conservation in subtropical mountain ranges. Northern sector of the Argentine Central Andes, The Cryosphere Discussion. https://doi.org/10.5194/tc-2016-232. In review.

Funk, M., Hoelzle, M. 1992. Application of a Potencial Direct Solar radiation model for investigating ocurrences of mountain permafrost. Permafrost and Periglacial Processes 3 (2), 139-142.

Haeberli, W. 1985. Creep of mountain permafrost; internal structure and flow of alpine rock glaciers. Mitteilugen der Versuchsanstalt fur Wassenbau Hydrologie and Glaziologie 77, 142 pp.

Haeberli, W., Hallet, B., Arenson, L., Elconin, R., Humlum, O., Kääb, A., Kaufmann, V., Ladanyi, B., Matsuoka, N., Springman, S., Vonder Mühll, D. 2006. Permafrost creep and rock glacier dynamics. Permafrost and Periglacial Processes 17, 189-214.

Humlum, O. 1998. The climatic significance of rock glaciers. Permafrost and Periglacial Processes 9, 375-395

Ikeda, A., Matsuoka, N. 2006. Pebbly versus bouldery rock glaciers: Morphology, structure and processes. Geomorphology 73 (3-4), 279-296.

Jenk, T., Graesslin-Ciric, A., Tobler, L., Gäggeler, H., Morgenstern, U., Casassa, G., Lüthi, M., Schmitt, J., Eichler, A., Schwikowski, M. 2015. The Mercedario ice core - an excellent archive for ENSO reconstruction. EGU General Assembly, Abstracts, 385 Vienna.

Kozlowski, E., Manceda, R., Ramos, V.A. 1993. Estructura. In: V.A. Ramos (Ed.), Geología $y$ recursos naturales de Mendoza. $12^{\circ}$ Congreso Geológico Argentino y $2^{\circ}$ Congreso Exploración de Hidrocarburos, Mendoza, pp. 235-256.

Leiva, J.C., Cabrera, G.A., Lenzano, L.E. 2007. 20 years of mass balances on the Piloto glacier, Las Cuevas river basin, Mendoza, Argentine. Global and Planetary Change 59, 10-16. https://doi.org/10.1016/j.gloplacha.2006.11.018.

Lliboutry, L. 1998. Glaciers of Chile and Argentina. In: R.S. Williams, J.G. Ferrigno, (Eds.), Satellite Image Atlas of Glaciers of the World: South America. USGS Professional Paper 1386-I, Online version 1.02.

Manceda, R., Figueroa, D. 1995. Inversion of the Mesozoic Neuquén rift in the Malargüe foldthrust belt, Mendoza, Argentina. In: A.J. Tankard, R. Suárez, H.J. Welsink (Eds.), Petroleum 
Basins of South America. American Association of Petroleum Geologists, Memoir 62, 369382.

Masiokas, M., Villalba, R., Luckman, B., Le Quesne, C., Aravena. J.C. 2006. Snowpack variations in the Central Andes of Argentina and Chile, 1951-2005: Large-scale atmospheric influences and implications for water resources in the region. Journal of Climate 19,6334-6352.

Masiokas, M.H., Christie, D.A., Le Quesne, C. 2016. Reconstructing the annual mass balance of the Echaurren Norte glacier (Central Andes, $33.5^{\circ} \mathrm{S}$ ) using local and regional hydroclimatic data. The Cryosphere 10 (2), 927-940. https://doi.org/10.5194/tc-10-927-2016.

Martini, M.A., Strelin, J.A., Astini, R.A. 2013. Inventario y caracterización morfoclimática de los glaciares de roca en la Cordillera Oriental argentina (entre $22^{\circ}$ y $25^{\circ} \mathrm{S}$ ). Revista Mexicana de Ciencias Geológicas 30 (3), 569-581.

Perucca, L., Esper Angillieri, M.Y. 2008. A preliminary inventory of periglacial landforms in the Andes of La Rioja and San Juan, Argentina, at about $28^{\circ}$ S. Quaternary International 190 , 171-179.

Perucca, L.P., Ésper Angillieri, M.Y., Martos, L. 2011. Inventario de glaciares de escombros en el área del Proyecto El Carmen, Andes Áridos de San Juan. In: Actas XVIII Congreso Geológico Argentino, Neuquén, pp. 1284-1285.

Ramos, V.A. 1985. El Mesozoico de la Alta Cordillera de Mendoza: reconstrucción tectónica de sus facies, Argentina. In: $6^{\circ}$ Congreso Geológico Chileno, Actas 1 (2), pp. 104-118, Antofagasta.

Ramos, V.A., Aguirre-Urreta, M.B., Álvarez, P.P., Cegarra, M., Cristallini, E.O., Kay, S.M., Lo Forte, G.L., Pereyra, F., Pérez, D. 1996. Geología de la región del Aconcagua, provincia de San Juan y Mendoza. Subsecretaría de Minería de la Nación. Dirección Nacional del Servicio Geológico, Anales 24, 1-510.

Scapozza, C., Lambiel, C., Baron, L., Marescot, L., Reynard, E. 2011. Internal structure and permafrost distribution in two alpine periglacial talus slopes, Valais, Swiss Alps. Geomorphology 132, 208-221.

Scholl, K.H. 2002. Mapeo geomorfológico del piso periglacial en los Andes Semiáridos. In: D. Trombotto, R. Villalba (Eds.), IANIGLA, 30 años de investigación básica y aplicada en Ciencias Ambientales, Mendoza, pp. 89-92.

Schrott, L. 1991, Global solar radiation, soil temperature and permafrost in the Central Andes, Argentina: a progress report. Permafrost and Periglacial Processes 2 (1), 59-66.

Schrott, L. 1996. Some geomorphological-hydrological aspects of rock glaciers in the Andes (San Juan, Argentina). Zeitschrift Für Geomorphologie, Suplementband 104, 161-173.

Strecker, M., Alonso, R., Bookhagen, B., Carrapa, B., Hilley, G., Sobel, E., Trauth, M. 2007. Tectonics and climate of the Southern Central Andes, Annual Review of Earth and Planetary Sciences 35 (1), 747-787.

Tapia Baldis, C.C., Trombotto Liaudat, D. 2015. Cinturones altitudinales criógenicos en la cuenca del río Bramadero, San Juan, Argentina. Acta Geológica Lilloana 27 (2), 146-158.

Tapia Baldis, C.C., Trombotto Liaudat, D., Villarroel, C., Otero, F. 2016 Modelling of mean annual air temperature (1979-2010) for the study of mountain permafrost in the SW of San Juan. In: F. Günther, A. Morgenster (Eds.), XI International Conference On Permafrost - Book of Abstracts Potsdam.

Trombotto, D., Buk. E., Hernández, J. 1997. Monitoring of mountain permafrost in the Central Andes, Cordón del Plata, Mendoza, Argentina. Permafrost and Periglacial Processes 8, 123 129.

Trombotto, D., Buk., E., Hernández, J. 1999. Rock glaciers in the Southern Central Andes (app. 331 S.L.) Mendoza, Argentina: a review. Bamberger Geographische Schriften 19, 145-173.

Trombotto Liaudat D., Lenzano M.G., Castro M. 2012. Inventory and monitoring of rock glaciers and cryogenic processes in the Central Andes of Mendoza, Argentina: Birth and extinction 
of a periglacial lake. In: Tenth International Conference on Permafrost-Proceedings. Salekhard, 419-425.

Villarroel, C.D., Forte, A.P., Tapia Baldis, C. 2016. Permafrost detection through the use of geophysical methods in the Blanco River Basin, San Juan, Argentinia. In F. Hünther, A. Morgenstern (Eds.), XI International Conference On Permafrost - Book of Abstracts, Bibliothek Wissenschaftspark Albert Einstein, Postdam.

Wahrhaftig, C., Cox, A. 1959, Rock glaciers in the Alaska Range. Bulletin of the Geological Society America 70, 383-436.

Yrigoyen, M.R. 1972. Cordillera Principal. In: A.F. Leanza (Ed.), Geología Regional Argentina. Academia Nacional de Ciencias, Córdoba, pp. 345-364.

Yrigoyen, M.R. 1976. Observaciones geológicas alrededor del Aconcagua. In: $1^{\circ}$ Congreso Geológico Chileno, Actas I, Santiago, pp. 168-190. 